model of spontaneous gastric perforation should allow these other factors to be evaluated.

\section{SUMMARY}

Spontaneous gastric perforations usually occur in well infants during the first 5 days of life. This study shows that a well infant ingests an average of $360 \mathrm{ml}$ air in $6 \mathrm{hr}$. This amount is sufficient to cause gastric rupture if entrapped in the stomach and not allowed to escape through the esophagus or small bowel. An experimental model utilizing eight rodents and six puppies showed that fluid could prevent the movement of air distally into the small bowel. The change of angle at the gastroesophageal junction when the gastric antrum was distended with air prevented proximal reflux. Rupture was produced in the eight rodents and in the three puppies less than 10 days of age but not in the puppies older than 10 days.

\section{REFERENCES AND NOTES}

1. Bukley, G., Goldman, H., and Silen, W.: Studies on an in vivo model of acute gastric dilatation. Amer. J. Surg., 117: 193 (1969).

2. Castleton, K. B., and Hatch. F. F.: Idiopathic perforation of the stomach in the newborn. Arch. Surg., 76: 874 (1958).

3. Elders, M. J., and Hughes, E.: Rupture of the stomach: Clinical and experimental study. Lancet, $86(3): 104$ (1966).

4. Herbut, P. A.: Congenital defect in the musculature of the stomach with rupture in the newborn infant. Arch. Path., 36: 91 (1943).

5. Hodges, D. J.: Gastro-oesophageal lacerations. Med. J. Aust., 778 (1965).
6. Hood, H. H.: Clinical considerations of intestinal gas. Ann. Surg., 163: 359 (1966).

7. Inouye, W. Y., and Evans, G: Neonatal gastric perforation: A report of six cases and a review of 143 cases. Arch. Surg. 88: 471 (1964).

8. Kneiszl, F.: Some data on the etiology of gastric rupture in the newborn. Biol. Neonatal, 4: 201 (1962).

9. Leger, J. L., Richard, P. M., Leonard, C., and Piette, J.: Ulcere gastrique perfore chez un nouvra-une avec survie. Union Med. Can., 79: 277 (1950).

10. Lloyd, J. R.: 1969. The etiology of gast rointestinal perforations in the newborn. J. Pediat. Surg., 4: 77 (1969).

1I. Meyer, J. L.. II: Congenital defects in the musculature of the stomach resulting in spontaneous gastric perforation in the neonatal period: A report of two cases. J. Pediat., 51: 416 (1957).

12. Parrish. R. A. Sherman, R. T., and Wilson, H.: Spontaneous rupture of the gastroenteric tract in the newborn: $A$ report of 13 cases and description of a characteristic x-ray finding. Ann. Surg., 159 (2): 244 (1964).

13. Plenk. H.: Z. Mikr.-Anat. Forsch., 26: 547, (1921).

14. Purcell, W. R. Perforation of the stomach in a newborn infant. Amer. J. Dis Child., 103: 66 (1962)

15. Shaker, I. J.. Schaefer. J. A., James, A. E., and White. J. J.: Aerophagia. a mechanism for spontaneous rupture of the stomach in the newborn. Amer. Surgeon, 39 (II): 619 (1973).

16. Shaw, A., Blanc, W. A., Santulli, T. V., and Kaiser, G.: Spontaneous rupture of the stomach in the newborn: A clinical and experimental study. Surgery, $58(3)$ : 561 (1965).

17. We wish to express our appreciation to the members of the Department of Radiology and Radiological Science (Dr. Martin W. Donner, Chairman). Mrs. Joseph Digel, Mr. Gary Novak, and Michatel Ryan provided technical assistance.

18. Requests for reprints should be addressed to: R. M. Heller, Jr., M.D.. Department of Radiology, The Johns Hopkins Medical Institutions, Baltimore, Md. 21205 (USA).

19. Accepted for publication August 14, 1975.

\title{
A Review: Relation between Invasiveness and the K1 Capsular Polysaccharide of Escherichia coli
}

\author{
MARK S. SCHIFFER, ELIZABETH OLIVEIRA, MARY P. GLODE, GEORGE H. MCCRACKEN, JR., \\ LARRY M. SARFF, AND JOHN B. ROBBINS(62)
}

Division of Bacterial Products, Bureau of Biologics, Bethesda, Maryland, and Department of Pediatrics, Southwestern Medical School at Dallas, Dallas. Texas. USA

Under certain conditions, Escherichia coli may invade the blood and localize in various tissues. The host factors and bacterial properties related to the penetration of $E$. coli through its usual supramucosal localization in the intestinal tract or from other sites are incompletely understood. Recently, a direct association between an invasive bacterial disease, neonatal meningitis, and a single $E$. coli structure, the $\mathrm{K} I$ antigen, has been reported (44). Our studies of the relation to disease and characteristics of the Kl antigen causing neonatal meningit is in this comparatively homogeneous patient population provide some insight into the mechanisms of $E$. coli invasiveness.

The term $\mathrm{K}$ antigens of $E$. coli, first introduced by Kauffmann and Valhne (32), was intended to designate an envelope or surface structure. Most of the 100 categorized $\mathrm{K}$ antigens (International Centre for Reference and Research on Escherichia, World Health Organization) are capsular polysaccharides, similar in their overall chemical, physical, and morphologic structure to the capsular polysaccharides of highly invasive bacteria such as meningococcus, pneumococcus, and Haemophilus influenzae type b $(4,37,38)$ Originally based upon serologic reactivity, more exact biochemical and genetic information has shown that the $\mathrm{K} 88$ and $\mathrm{K} 89$ antigens are fimbriae or pili (episomal-directed proteins) that serve as attachment factors to mammalian cells (54) and that K80 antigen is a component of the somatic or $\mathrm{O}$ antigen (25).

$E$. coli $\mathrm{K}$ capsular polysaccharides are linear co- or homopolymers composed of one or several monosaccharides joined by glycosidic and/or phosphodiester bonds. A neutral $\mathrm{pH}$, they have a net negative charge because of these phosphodiester bonds or uronic acid components. The relation between capsular polysaccharides and $E$. coli invasiveness was first shown by Smith (52) and later by Kauffman (31). Surveillance data has shown that $E$. coli, isolated from extraintestinal sites, have acidic capsular polysaccharides (39). These invasive strains are found in normal intestinal tract along with a great variety of non-K antigen bearing $E$. coli. Further studies demons 1 rated that $\mathrm{K}$ antigens, isolated from $E$. coli that had infected renal parenchyma, had a higher molecular weight 
and were in higher concentration per bacterial cell than $\mathrm{K}$ antigens from strains of the same serotype confined to the bladder or intestinal tract $(14,26,39)$. The mechanism by which the $\mathrm{K}$ capsular polysaccharides conferred renal parenchymal invasiveness to $E$. coli strains was postulated to be their anticomplementary effect $(14,15)$. Further, some $E$. coli $\mathrm{K}$ antigens are immunochemically related to the capsular polysaccharides of highly invasive bacteria, including Neisseria meningitidis group B and group C, Diplococcus pneumoniae types 1, 2, 4, 7, 10, and 23 and $H$. influenzae type $b(5,17,21,45,50,61)$. This evidence suggests that the $K$ capsular polysaccharides are important determinants of invasive $E$. coli disease.

\section{NEONATAL E. COLI MENINGITIS}

Human and animal neonates are particularly susceptible to $E$. coli septicemic diseases, including meningitis $(6,19)$. Despite advances in antimicrobial chemotherapy, the combine mortality and morbidity of neonatal meningitis and septicemia remains high: there are few normal survivors $(28,19,34,35,41,57)$. There is little information regarding the antigenic, metabolic characteristics and origin of cerebral spinal fluid (CSF) $E$. coli related to the pathogenesis of neonatal meningitis. The Escherichia genus is antigenically quite complex, comprising some 155 somatic (O), 100 capsular $(\mathrm{K})$, and 50 flagella $(\mathrm{H})$ antigens. Curiously, there have been no reported descriptions of serotypes of CSF isolates from newborns. Based upon the high specific activity of $\operatorname{IgM}$ antibodies as compared with $\operatorname{IgG}$ antibodies in several biologic assays, including complement-dependent bactericidal reaction and opsonization and protection tests, several investigators proposed that the deficiency of this immunoglobulin in the newborn was related to increased susceptibility of infants to gram-negative infections (12). In addition, other developmental deficiencies, such as diminished serum complement proteins, low levels of opsonins, and lesser phagocytic and bactericidal activity of lymphoid cells, have been implicated $(36,51,55,56)$. However, an association between the $E$. coli $\mathrm{K} 1$ capsular polysaccharide and neonatal meningitis should direct attention to the organism as well as the host to account for newborn susceptibility toward $E$. coli septicemia and meningitis (44).

\section{UNUSUAL CHARACTERISTICS OF E. COLI KI ANTIGEN}

Grados and Ewing (17) reported that an E. coli isolated from the spinal fluid of a newborn agglutinated with meningococcus group $B$ antiserum. More detailed studies by Kasper et al. (30) showed that the shared antigen between meningococcus group B and the $E$. coli strain O7:K I(L): NM, reported by Grados and Ewing, was the capsular polysaccharide antigens of these two bacterial species. The chemical composition of the $E$. coli $\mathrm{KI}$ polysaccharide, first described by Barry and Goebel $(2,3)$, is a polymer of $N$-acetylneuraminic acid. Further studies have shown that this $E$. coli polysaccharide was structurally similiar or identical with the meningococcal group B polysaccharide (33). In addition to their structural similiarity, both the purified $E$. coli $\mathrm{K} I$ and meningococcus group B polysaccharides will induce the formation of serum antibodies in most young adults (33). When injected as whole formaldehyde-treated encapsulated organisms into laboratory animals, both meningococcus group B and $E$. coli fail to induce the usual amount of serum anticapsular antibodies elicited by other encapsulated bacteria. In contrast to meningococcus groups $\mathrm{A}$ and $C$, asymptomatic nasopharyngeal carriage of meningococcus group B did not elicit anti-group B polysaccharide antibodies (61). Furthermore, only a small fraction of adults recovering from meningococcal group B septicemic diseases, including meningitis, responded with the expected level of serum anticapsular antibodies as compared with patients convalescent from meningococcal group A or group $\mathrm{C}$ meningitis (7). Although the clinical setting is not strictly comparable, most children synthesize anti- $O$ but not anti-Kl antibodies after urninary tract infections with these organisms (29).
PREVALENCE OF KI ANTIGEN AMONG CSF AND BLOOD ISOLATES FROM HUMAN NEWBORNS WITH $E$. COLI DISEASE

The prevalence of the $\mathrm{Kl}$ antigen among $E$. coli isolates from neonates with invasive diseases including meningitis and from diseased and healthy individuals of all ages was compared. Among 163 neonates with $E$. coli meningitis, $126(77 \%)$ had K I-containing organisms. These organisms were CSF isolates supplied to us by participating members of The Cooperative Neonatal Meningitis Study Group, the Department of Pediatrics at the University of Goteborg, Sweden, and by many other cooperating institutions and physicians directly concerned with the care of these patients $(34,44)$. Similar results were obtained by studying the organisms submitted to the Enterobacteriology Laboratory, Center for Disease Control, from the years 1967 through 1973 (Table 1).

A direct relation between the $\mathrm{KI}$ antigen and meningitis was shown by the observation that only $40 \%$ of $E$. coli blood isolates in infants with septicemia without meningitis were $\mathrm{Kl}$ strains. This might be explained by the fact that $\mathrm{Kl}$-containing strains are more invasive, can persist in the circulation longer and in higher concentrations, and can localize ultimately in the meninges. A similiar tendency for $\mathrm{KI}$ to be found more often in $E$. coli infections in children as adults was observed among urinary tract isolates. Approximately $20 \%$ of urinary $E$. coli from children were $\mathrm{Kl}$ in contrast to approximately $10 \% \mathrm{Kl}$ strains found among urinary tract isolates in adults including pregnant women (29).

\section{ANTIGENIC AND METABOLIC CHARACTERISTICS OF CSF $E$ COLI KI STRAINS}

The most frequently encountered somatic antigens of the CSF $\mathrm{Kl}$ isolates were $\mathrm{O} 18 \mathrm{ac}, \mathrm{O} 7, \mathrm{O}$, and 016 . These $O$ antigens comprise about two thirds of the CSF K I strains (46). Other CSF $\mathrm{K} 1 \mathrm{O}$ serotypes were $O 132, O 123, O 83, O 134, O 156$. A significant proportion of the CSF $\mathrm{KI}$ isolates spontaneously agglutinated, presumably because of deficient $O$ polysaccharide side chains of their somatic antigens. $\mathrm{H} 7$ and $\mathrm{H} 6$ were the most common flagellar antigens although at least half the CSF strains could not be typed with available antisera. Late lactose fermentation, an unusual biochemical characteristic of $E$. coli, was observed among $15 \%$ of $\mathrm{K} 1$ strains isolated from healthy and diseased individuals. One of the CSF E. coli strains reacted with meningococcus C. This organism, strain N67 O13:K?:NM also reacts with equine meningococcus group $\mathrm{B}$ antiserum and will be the subject of a future report. No CSF organisms reacted with pneumococcus type 1 and 3 or $H$. influenzae type b antiserum. One strain isolated from the blood of the neonate without meningitis cross-reacted with pneumococcus type 3 , indicating it had the $\mathrm{K} 7$ capsular polysaccharide

Table I. Prevalence of KI antigen among neonatal cerebral spinal fluid (CSF) and blood E. coli isolates sent to enterobacteriology laboratory, Center for Disease Control. 1968-19731

\begin{tabular}{lcc}
\hline \multicolumn{1}{c}{ Source of organism } & K1 positive & K1 negative \\
\hline CSF & $12^{2}$ & 3 \\
$\begin{array}{l}\text { Blood (presence or absence of } \\
\quad \text { meningitis not stated) }\end{array}$ & $15^{2}$ & 10 \\
Miscellaneous CSF isolates & & \\
Myelomeningocoele patients (CSF) $_{\text {My }}$ & 0 & 2
\end{tabular}

${ }^{1}$ The organisms were identified as $\mathrm{Kl}$ by immunodiffusion of $E$. coli saline extracts with equine meningococcal group B antiserum. The organisms were kindly supplied by Dr. George Hermann, Center for Disease Control.

${ }^{2}$ One KI CSF strain and three $\mathrm{Kl}$ blood isolates, all of the same $\mathrm{O}$ and $H$ serotype, were sent from different patients at the same hospital at the same time.

${ }^{3}$ From older children whose underlying disease was not stated. 
(46). There was no association between the KI capsular polysaccharide and other $E$. coli structures such as the $O$ and $\mathrm{H}$ antigens.

Recently, it has been shown that outer membrane proteins of encapsulated meningococci are related to their disease potential $(11,16,22,49)$. Furthermore, serum bactericidal activity, detectable after nasopharyngeal carriage or disease with meningococcal group B organisms, is due to antibodies directed toward outer membrane proteins. These proteins exhibit polymorphism which has formed the basis for a typing scheme $(11,16)$. Although there are at least 12 different menigococcal group B outer membrane proteins, types 2 and 9 account for about $85 \%$ of the meningitis isolates. In contrast, at least 9 other serotypes have been isolated from asymptomatic carriers. The demonstration of these heterogeneous outer membrane proteins from $E$. coli by Schnaitman (49) suggests that these antigens should be studied from Kl strains isolated from various sources.

The capsular polysaccharide content of KI E. coli from the CSF, blood, and stools of healthy and sick neonates and the blood and stools of adults were assayed for their $N$-acetylneuraminic acid content by the thiobarituric reaction and for their immunologically reactive content by the Mancini technique using meningococcus group B antiserum. These experiments showed that the K 1 capsular content was similar among strains isolated from the CSF and blood of sick neonates or the stools of healthy infants, children, and adults, suggesting that the total amount of encapsulation was not related to virulence. Thus, it is not possible to recognize a "virulent" $E$. coli $\mathrm{K} I$ strain by the determination of its capsular content (47).

\section{VIRULENCE OF E. COLI KI STRAINS}

Despite the use of antimicrobials, the mortality of neonatal $E$. coli meningitis is approximately $35 \%$ and morbidity among survivors is approximately $50 \%(18,19,34,35,41,57) . \mathrm{K} 1$ strains are highly virulent for mice (59). Accordingly $L D_{80}$ values for 43 $\mathrm{K} 1$ and 9 non-K 1 CSF isolates in a mucin-enhanced, lethal mouse infection assay were compared $(34,44)$. The mean $L_{50}$ for the $\mathrm{K} I$ organisms was 168 (range $2-800$ ) and the mean for the non-KI strains was $5.8 \times 10^{4}$ (range $790-3.9 \times 10^{5}$ ). No differences in antibiotic sensitivities were observed among the $\mathrm{KI}$ or $\mathrm{KI}$-negative CSF strains.

\section{RELATIONSHIP BETWEEN CONCENTRATION AND PERSISTENCE OF SERUM AND CSF KI ANTIGEN AND MORTALITY AND MORBIDITY OF NEONATAL MENINGITIS}

To study further the relationship between the $\mathrm{Kl}$ antigen concentration and the pathogenesis of neonatal $E$. coli meningitis, the presence and the of the $K 1$ antigen in serum and CSF of patients was studied using countercurrent immunoelectrophoresis (CIE) (34). CSF specimens from 41 of the 48 infants with $E$. coli $\mathrm{K}$ meningitis were available. The $\mathrm{Kl}$ antigen was detected in the CSF from 29 of 41 infants (71\%). With the exception of 4 infants, CSF cultures were positive 1.4 days longer than CSF K I antigen was detectable. Higher $\mathrm{Kl}$ antigen levels and longer duration of detection were present among those who succumbed to the disease or had an abnormal outcome. Among the group without detectable neurologic abnormalities only half had CSF Kl antigen. Their level was lower and the duration of antigenemia was shorter. A similiar direct relation was obtained for the clinical outcome and serum $\mathrm{K} 1$ antigen concentration. Of those infants with a normal outcome, 3 of 14 had detectable $\mathrm{K} 1$ antigen as contrasted to 8 of 11 with detectable serum $\mathrm{Kl}$ antigen who succumbed.

The mortality of those with $\mathrm{Kl}$ meningitis was significantly higher than those with non-Kl disease; their cultures remained positive longer and they had a higher frequency of relapse after "successful" antimicrobial chemotherapy. As has been shown for $H$. influenzae type b $(1,24,58) D$. pneumoniae $(10,23), N$. meningitidis $(8,9)$, and Klebsiella pneumoniae $(42)$, a direct re- lation was also demonstrable between the CSF and or serum capsule concentration and the mortality and morbidity in neonatal $E$. coli meningitis. The CIE assay may prove to be a valuable diagnostic test and provide information for prognosis and therapy for neonatal $E$. coli meningitis.

Invasiveness of $E$. coli $\mathrm{Kl}$ strains was investigated in a $\mathrm{HeLa}$ cell in vitro model and in the conjunctiva of rabbits (48). $\mathrm{K} /$ organisms were not invasive by these two assay systems as contrasted to Shigella strains which penetrated the HeLa cells and caused purulent conjunctivitis and corneal scarring in rabbits.

\section{IN VIVO EFFECT OF KI POLYSACCHARIDE INJECTION IN MICE}

The possibility that the circulating $K l$ antigen exerted a nonspecific depression of resistance mechanisms was examined in a mucin-enhanced, $E$. coli $\mathrm{Kl}$ lethal infection in mice. The $\mathrm{KI}$ polysaccharide was purified from two E. coli strains, $O 7$ and $O 64$. The serum half-life of the KI antigen in 15-18-g, all-purpose $\mathrm{NIH}$ mice, was determined by measuring the concentration by radial immunodiffusion at various intervals after intravenous injection of 0.5 and $1.5 \mathrm{mg}$ of the purified antigen. The half-life of the intravenously injected $K 1$ polysaccharide was approximately 8.0 $\mathrm{hr}$. The $L D_{s 0}$ of two K I strains was not affected by injecting $0.5 \mathrm{mg}$ $\mathrm{K} 1$ antigen immediately or at various intervals up to 2 weeks before challenge with the mucin-suspended $E$. coli (Table 2).

The purified $\mathrm{K} 1$ polysaccharide did not induce protection. It was concluded that $E$. coli virulence in mice was not related to serum $\mathrm{KI}$ antigen; this indicated that the capsular polysaccharide, per se, is not a general inhibitor of resistance mechanisms.

\section{MECHANISMS OF IMMUNITY}

Anticapsular antibodies confer immunity to diseases caused by $H$. influenzae type b, meningococci, and pneumococci. To study the role of anti-KI antibodies, goat meningococcal group $B$ antiserum was applied to a meningococcal group B polysaccharide-sepharose $4 \mathrm{~B}$ derivative and the adsorbed $\mathrm{Kl}$ antibodies purified by elution with $3 \mathrm{M}$ KCNS. Use of the purified anticapsular antibodies avoids the problem of interpreting results with antisera prepared by injection of whole $E$. coli with their many noncapsular, cross-reacting antigen-antibody systems. A highly protective effect of this purified meningococcus group B antibody with Kl activity was observed with gastric mucin or saline suspensions $E$. coli in a mouse lethal infection model (44). The specificity of this anti-KI antibody was verified by its lack of effect upon the LD $_{50}$ of non-K 1 strains. Wolberg and deWitt (59) and Kaijser (27) have shown that Kl antibodies, induced by the injection of whole $E$. coli organisms, will induce protection. Thus, immunity to neonatal $E$. coli meningitis may be mediated by anti-capsular antibodies. The source of these proposed protective $\mathrm{K} \mathrm{I}$ antibodies in newborns may be maternal serum or colost rum.

Table 2. Mouse $L D_{50}$ of Escherichia coli 062:K I:H6 challenge after intravenous injection of purified KI polysaccharide ${ }^{1}$

\begin{tabular}{ccc}
\hline & \multicolumn{2}{c}{ LD $_{50}$} \\
\cline { 2 - 3 } $\begin{array}{c}\text { Time after K1 } \\
\text { injection }\end{array}$ & $\mathrm{K} 1$ injected & Controls \\
\hline $0.5 \mathrm{hr}$ & $3.6 \times 10^{3}$ & $2.35 \times 10^{3}$ \\
$24 \mathrm{hr}$ & $1.45 \times 10^{2}$ & $1.08 \times 10^{2}$ \\
18 days & $2.82 \times 10^{3}$ & $0.89 \times 10^{3}$ \\
\hline
\end{tabular}

${ }^{1}$ Five groups of five NIH-all purpose 15-20-g mice each were injected intravenously with $0.5 \mathrm{mg}$ purified $E$. coli $\mathrm{K} 1$ polysaccharide. They were then challenged with $E$. coli $\mathrm{O} 62: \mathrm{HI}: \mathrm{H} 6$ suspended in mucin and the $\mathrm{LD}_{50}$ calculated according to the method of Reed and Muench (43). 


\section{PATHOGENESIS OF DISEASE}

There are similarities between neonatal $E$. coli meningitis and meningitis in children and adults caused by the usual pathogenic encapsulated bacteria. First, these pathogens are encapsulated with an acidic polysaccharide. Second, a protective effect of "natural" and/or immunization-induced anticapsular antibodies can be demonstrated. Third, the mortality and morbidity of meningitis is related to the concentration and persistence of capsular polysaccharides in the CSF and/or the blood. With the exception of epidemics, the nasopharyngeal carriage or virulent types of meningococci, $H$. influenzae type $b$ and pneumococci is quite low. Accordingly, studies were undertaken to determine the frequency with which $E$. coli $\mathrm{Kl}$ strains could be found in the normal gastrointestinal flora and other sites of newborns, mothers, and hospital personnel (47). E. coli strains were collected from urine cultures, rectal swabs from healthy newborns, CSF cultures of neonates with meningitis and, where possible, stool cultures from these patients, their mothers, and hospital personnel, rectal swabs from pregnant women at delivery, and nonpregnant females from family planning clinics and individuals of all ages from outpatient departments at various hospitals. The detection of the $\mathrm{K} l$ strains was done by the antiserum agar technique using equine meningococcus group $B$ antiserum prepared by intravenous injection of formaldehyde-fixed meningococcus group B (strain BII). This antiserum contained approximately $0.5 \mathrm{mg}$ anti-K I capsular polysaccharide antibody $/ \mathrm{ml}$. Swabs were streaked onto antiserum agar plates and incubated overnight at $37^{\circ}$. After initial examination for halos of precipitation surrounding the individual colonies, the plates were incubated for an additional $24 \mathrm{hr}$ at $4^{\circ}$ and reinspected using a high intensitiy spotlight against a dark background. Analysis of 664 rectal swab cultures, positive for $E$. coli $\mathrm{K}$ l strains, revealed pure or almost pure growth in $35 \%$, moderately heavy growth (greater than 10 of $E$. coli $\mathrm{K} /$ colonies) in $31 \%$, and less than 10 halo-producing colonies in the remainder of the cultures. The antiserum agar technique was compared with the conventional procedure of picking isolated colonies and $K$ typing by slide agglutination and/or immunoelectrophoresis. It was found that in the cultures with a light growth a higher yield of K1-positive organisms was achieved with the antiserum agar plates. In those swabs where the KI organism was predominant, there was no significant difference between the two techniques. Therefore, the antiserum agar technique seemed to be more sensitive in spotting $\mathrm{Kl}$ organisms than analysis of individual colonies from standard media. Further, $E$. coli are usually identified by $24-\mathrm{hr}$ lactose fermentation on conventional media. The reliance on this fermentation property may result in missing many K I strains that are late lactose fermentors (47). In healthy newborns, $E$. coli $\mathrm{Kl}$ strains were found in approximately one-fifth of newborns (range 7-38\%). Prevalence rates within the same nursery at different times were variable. For instance, KI strains were detected in only 1 of $100 \mathrm{E}$. coli from neonates in Mexico City in December 1973 and May 1974. However, 7 of $20(35 \%)$ had $\mathrm{K}$-positive strains when this nursery was restudied in October 1974. That same variation was observed in the premature nursery at Parkland Memorial Hospital. Despite no obvious changes in the routine handling of these babies or in nursing personnel. during the first 19 weeks $10.32 \%$ of the infants had detectable $E$. coli $\mathrm{K} /$ in contrast to the next 8 weeks, where the $\mathrm{KI}$ prevalence rate fell to $0-11 \%$ (mean $6.6 \%$ ). In the last 4 weeks of the study, KI strains were found in $11 \quad 16 \%$ (mean $13.5 \%$ ) of these rectal swabs. The reason for this variability in the $E$. coli $\mathrm{K} 1$ prevalence rates in stool cultures in an individual nursery was unknown. In a study of individuals varying in age from premature infants to adults, including pregnant women, it was found that approximately $20.40 \%$ of individuals possessed $E$. coli $\mathrm{Kl}$ strains. Acquisition of $E$. coli $\mathrm{Kl}$ in healthy term infants was directly related to the presence of the same organism in the maternal stool. Among 97 mothers studied for $\mathrm{Kl}$ organisms at delivery, $44 \%$ had E. coli strains. Two-thirds of neonates born to these K1-positive mothers had $\mathrm{Kl}$ strains, whereas only $11 \%$ of infants born to Kl-negative mothers had Kl-positive stool cultures. Among full term babies who eventually acquired $E$. coli $\mathrm{K} 1,77 \%$ had positive rectal cultures by the second day and $91 \%$ by the third day. Studies comparing the time of acquisition by infants born to K1-positive mothers suggested that $\mathrm{Kl}$ strains were acquired by these babies more rapidly than those infants who had $\mathrm{Kl}$ in their stools when discharged from the hospital but whose mothers were $\mathrm{K} I$ negative. Term infants acquired their Kl strains more rapidly than premature infants, who were kept in strict isolation. This latter observation suggests that mothers are the chief source of $\mathrm{K} l$ organisms for most newborns. However, KI strains can be acquired from nonmaternal sources, such as hospital personnel.

$E$. coli flagella $(\mathrm{H})$ and somatic $(O)$ serotypes of the $\mathrm{K} 1$ strains from normal stools were compared with those strains isolated from the CSF. To date, our conclusion is that there is no difference in the prevalence rate of $\mathrm{H}$ and $\mathrm{O}$ serotypes of $\mathrm{KI}$ strains isolated from the CSF when compared with Kl strains taken from stools of healthy individuals.

Rectal swab cultures were obtained from 17 mothers whose infants had $E$. coli $\mathrm{K} 1$ meningitis; 11 mothers had the same $\mathrm{O}$ and $H$ serotype of $E$. coli as that causing the meningitis. In an additional mother-infant pair, $E$. coli $O 83: \mathrm{K} 1: \mathrm{H} 2$ was cultured from multiple sites of the infant and from the maternal urine but a different serotype was isolated from the maternal rectal swab. These studies indicate that in $E$. coli $\mathrm{K} 1$ meningitis, the offending organism can be isolated from the mother, strongly suggesting that this is the direct source.

Thus, in contrast to the low carriage rate of the virulent capsular types of pneumococci, meningococci, and $H$. influenzae type b. $E$. coli $\mathrm{Kl}$ organisms are detected in approximately $20-30 \%$ of individuals of all ages. Furthermore, $\mathrm{K} I$ strains are the predominant organisms in those infants have $\mathrm{Kl}$-positive rectal swabs. Accordingly, differences in the rate and degree of exposure do not adequately explain the age relationship of $E$. coli $\mathrm{KI}$ meningitis in the neonatal period. Similar KI prevalence rates in newborns have been reported by $\emptyset$ rskov and Sorensen (40). Assay of serum KI antibodies, using the ELISA technique, has shown that this antibody is infrequently detected in the serum of normal adults. Further, in the goat and horse sera prepared by repeated injection of formaldehyde-treated meningococcus group B organisms, virtually all the detectable antibody was of the IgM type (13). Kaijser and Hanson (28) have found that $\mathrm{Kl}$ antibodies are prevalent in colostral $\lg$ A. These preliminary experimental data suggest that colostral anticapsular antibodies may exert at different protective role in the pathogenesis of $E$. coli disease in neonatal meningitis than the role mediated by serum antibodies in children and adults.

The $\mathrm{Kl}$ is the most frequent capsular antigen serotype found in urinary tract infections in infants and children (26). Furthermore, approximately $10-15 \%$ of $E$. coli blood cultures in adults are $\mathrm{KI}$ organisms. Thus, the mechanisms of invasiveness and immunity that are critical in determining the pathogenesis of neonatal $E$. coli meningitis should provide important information in understanding other common and serious $E$. coli diseases

\section{SUMMARY}

The conclusions from our studies to date may be summarized as follows. (l) Invasive $E$. coli strains causing neonatal meningitis are encapsulated. At least $80 \%$ of those strains inducing mengitis are $\mathrm{K} 1$ and approximately $40 \%$ of those strains isolated from infants with septicemia but without meningitis are also $\mathrm{Kl}$. Invasiveness is best related to the $\mathrm{KI}$ antigen and not to $E$. coli $\mathrm{O}$ and $\mathrm{H}$ antigens. (2) The capsular content of CSF strains is not related to their invasiveness. In contrast to observations reporting higher $K$ capsular polysaccharide content and molecular weight of $E$. coli invading the renal parenychma as compared with those $E$. coli 
confined to the bladder or in the stool, there were no differences among CSF K 1 strains. Sepculation as to the mechanism of the invasive properties conferred by acidic capsular polysaccharides may be derived from the literature. Unencapsulated or "rough bacteria" are susceptible to the bactericidal action of agammaglobulinemic sera $(15,53)$. When injected into precolostral (agammaglobulinemic but complement containing), cesarian-delivered, and antigen-deprived piglets, unencapsulated bacteria are rapidly cleared from the circulation. In contrast, smooth bacteria injected into these same animals circulate without detectable splenic or hepatic clearance, multiply, and result in the death of these animals. The mechanism of the resistance of encapsulated bacteria has been postulated to be due to the inaccessibility of the deep somatic antigen structures capable of activating the alternate complement pathway system. Thus, opsoninization and other host complement-dependent activities may of necessity be antibody mediated for encapsulated bacteria. This complement resistance of encapsulated organisms may be quanititative and studies should be done to determine differences among various K $\mid E$. coli strains. (3) $\mathrm{K} 1$ strains are widely prevalent among infants, children, and adults and are quickly transmitted to infants. In most cases the source of the infecting strain in diseased infants is the mother. However, transmission from attendants, demonstrable in our studies, is also a possible mechanism. (4) A protective role of serum anticapsular antibodies in animal models has been demonstrated. Our initial observations indicating low serum $\mathrm{K} 1$ antibodies in the general population and the finding that $\mathrm{Kl}$ antibodies are predominantly IgM in two animal species studied so far suggest that colostral $\mathrm{K} I$ antibodies may be important in conferring immunity to this disease.

\section{REFERENCES AND NOTES}

1. Alexander, H. E.: Experimental basis for treatment of Haemophilus influenzae infections. Amer. J. Dis. Child., 66: 160 (1943).

2. Barry, G. T.: Coliminic acid, a polymer of $\mathrm{N}$-acetylneuraminic acid. J. Exp. Med., 107: 507 (1958).

3. Barry, G. T., and Goebel, W. F.: Coliminic acid, a substance of bacterial origin related to siatic acid. Nature, 179: 206 (1957).

4. Bolanos, R., and deWitt, C. W.: Isolation and characterization of the KI (L) antigen of Escherichia coli. J. Bacteriol., 91: 987 (1966).

5. Bradshaw, M. W., Schneerson, R., Parke, J. C., Jr., and Robbins, J. B.: Bacterial antigens cross-reactive with the capsular polysaccharide of Haemophilus influenzae type b. Lancet, $i$ : 1095 (1971).

6. Brambell, F. W. R.: The transmission of passive immunity from mother to young. N.-Holland Res. Monogr. Frontiers Biol., 18 (1970).

7. Brandt, B. L., Wyle, F. A., and Artenstein, M. S.: A radioactive antigen-binding assay for Neisseria meningitidis polysaccharide antibody. J. Immunol., 108: (1972).

8. BuKantz, S. C., Gara, P. F., and Bullowa, J. G. M.: Capsular polysaccharides in the cerebrospinal fluid of patients with purulent meningitis. J. Clin. Invest.. 30: 582 (1942).

9. Coonrod, J. D.: Physical and immunologic properties of pneumococcal capsular polysaccharide produced during human infection. J. Immunol., /12: 2193 (197).

10. Edwards, E. A.: Immunologic investigations of meningococcal disease. I. Groupspecific Neisseria meningitidis antigens present in the serum of patients with fulminant meningococcemia. J. Immunol., 106: 314 (1971).

11. Frasch, C. E., and Chapman, S. S.: Classification of Neisseria meningitidis Group B into distinct serotypes. Serological typing by a microbiological method. Infect. Immunol., 5: 98 (1972): III. Application of a new bactericidal inhibition technique to the distribution of serotypes among cases and carriers. J. Infect. Dis., 127: 149 (1972).

12. Gitlin, D., Rosen, F. S., and Michael, J. G.: Transient $19 \mathrm{~S}$ gamma I globulin deficiency in the newborn infant and its significance. Pediatrics, 31: 197 (1963).

13. Glode, M. P., Allen, P., and Robbins, J. B.: Characterization of equine meningococcal group B anticapsular antibody: Precipitating. mouse-protective, bactericidal, physico-chemical and antigenic activity. (In preparation)

14. Glynn, A. A., Brumfitt, W., and Howard, C. J.: K antigens of Escherichia coli and renal involvement in urinary-tract infections. Lancet, $i$ : 514 (1971).

15. Glynn, A. A., and Howard, R. J.: The sensitivity to complement of strains of Escherichia coli relative to their K content. Immunology, 18: 331 (1972).

16. Gold, R., and Wyles, F. A.: New classification of Neisseria meningitidis by means of bactericidal reactions. Infect. Immunol., I: 479 (1970).

17. Grados, O., and Ewing, W. H.: Antigenic relationship between Escherichia coli and Neisseria meningitidis. J. Infect. Dis., 122: 100 (1970).

18. Groover, R. V., Sutherland, J. M., and Landing, B. H.: Purulent meningitis of newborn infants: Eleven year experience in the antibiotic era. N. Engl. J. Med. 164: $1115(1961)$.
19. Haggerty, R. J., and Ziai, M.: Acute bacterial meningitis. Advan. Pediat., /3: 129 (1964).

20. Hanson, L. A., Carlsson, B., Ahlstedt, S., Svanborg, C., and Kaijser, B.: Immune defense factors in human milk. Mod. Probl. Paediat., 15: 63 (1975).

21. Heidelberger, M.. Jann, B., Jann, K., Ørskov, I., Фrskov, F., and Westphal, O.: Relation between structures of the K polysaccharides of Escherichia coli and cross-reactivity in pneumonsera. J. Bacteriol., 95: 2415 (1968).

22. Hill, J. C., Peterson, N. R., and Weiss, E.: Characterization of spheroplast membranes of Neisseria meningitidis Group B. Infect. Immunol., 5: 612 (1972).

23. Hoffman, T. A., and Edwards, E. A.: Group-specific polysaccharide antigen and humoral antibody response in disease due to Neisseria meningitidis. J. Infect. Dis., 126: 636 (1972).

24. Ingram, D. L., Anderson, P., and Smith, D. H.: Countercurrent immunoelectrophoresis in the diagnosis of systemic diseases caused by Hemophilus influenzae type b. J. Pediat., 81: 1156 (1972).

25. Jann, B., Jann, K.. Schmidt, G., Фrskov, I., and Фrskov, F.: Immunochemical studies of the polysaccharide surface antigens of Escherichia coli O100:K?:(B):H2. Eur. J. Biochem., 15: 29 (1970).

26. Kaijser, B.: Immunology of Escherichia coli: $\mathbf{K}$ antigen and its relation to urinary-tract infection. J. Infect. Dis., 127: 670 (1973).

27. Kaijser, B.: $E$. coli $O$ and $\mathrm{K}$ antigens and protective antibodies in relation to urinary tract infection. Thesis submitted to University of Goteborg, Goteborg. Sweden (1974).

28. Kaijser, B., and Hanson, L. A.: Unpublished data

29. Kaijser, B., Jodal, U., and Hanson, L. A.: Studies on antibody response and tolerance to $E$. coli $\mathrm{K}$ antigens in immunized rabbits and children with urinary tract infection. Int. Arch. Allergy, 44: 260 (1973).

30. Kasper, D. L., Winkelhake, J. L., Zollinger, W. D., Brandt, B. L., and Artenstein. M. S.: Immunochemical similiarity between polysaccharide antigens of Escherichia coli $07: \mathrm{K}](\mathrm{L}): \mathrm{NM}$ and Group B Neisseria meningitidis. J. Immunol., ll0: 262 (1973).

31. Kauffmann, F.: On the significance of $L$ antigens for the serology, immunology and pathogenicity of Escherichia species. Zbl. Bakter Hyg. I. Abt. Orig. A. 229: 178 (1974)

32. Kauffmann, F., and Vahine, G., Uber die nedeutung des serologischen formenwechsels fur die bakteriophagen-wirkung in der Coli-Gruppe. Acta Path. Microbiol. Scand., 22: 119 (1945).

33. Liu, T. Y., Gotschlich, E. C., Dunne, F. T., and Jonssen, E. K.: Studies on the meningococcal polysaccharides. 11. Composition and chemical properties of the Group B and Group C polysaccharide J. Biol. Chem.. 246: 4703 (1971).

34. McCracken, G. H. Jr., Sarff, L., Glode, M. P., Mize, S. G., Schiffer. M. S.

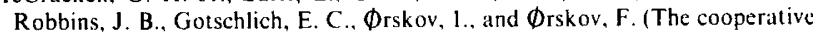
Neonatal Meningitis Study Group): Relation between Escherichia coli KI caspular polysaccharide antigen and clinical outcome in neonatal meningitis. Lancet, ii: 246 (1974).

35. McCracken, G. H., Jr., and Shinefield, H.: Changes in the pattern of neonatal septicemia and meningitis. Amer. J. Dis. Child., 1/2: 33 (1966).

36. Miller, M. E.: Phagocytosis in the newborn infant: Humoral and cellular factors. J. Pediat., 74: 255 (1969).

37. Prskov, I., and Prskov, F.: The K antigens of Escherichic coli. Re-examination and re-evaluation of the nature of $\mathrm{L}$ antigens. Acta Path. Microbiol. Scand. B. 78: 593 (1970)

38. Orskov, I., Grskov, F., Jann, B., and Jann, F.: Acidic polysaccharides: Antigens of a new type from $E$. coli capsules. Nature, 200: 144 (1963)

39. Osrkov, F., Orskov. I., Jann, B., and Jann, K.: Immunoelectrophoretic patterns of extracts from all Escherichia coli $\mathrm{O}$ and $\mathrm{K}$ antigen test strains: correlation with pathogenicity. Acta Path. Microbiol. Scand. B, 79: 142 (1971).

40. Orskov, F., and Sørensen, K. B.: The effect of breast feeding and bottle milk upon Escherichia coli serotypes in newborn stool. Brit. Med. J. (In press)

41. Overall, J. C., Jr.: Neonatal bacterial meningitis: Analysis of predisoposing causes and outcome compared with matched subjects. J. Pediat., 76: 499 (1970)

42. Pollock, M.: Clinical significance of capsular antigen in patients with Klebsiella infections. (In press)

43. Reed, L. J., and Muench, H.: A simple method for estimating fifty percent endpoints. Amer. J. Hyg., 126: 514 (1937).

44. Robbins. J. B., McCracken, G. H., Gotschlich, E. C., Drskov, F., Drskov, I., and Hanson, L. A.: Escherichia coli K1 capsular polysaccharide associated with neonatal meningitis. N. Engl. J. Med., 290: 1216 (1974).

45. Robbins, J. B., Myerowitz, R. L., Whisnant, J. K.. Schneerson, R., Handzel, Z T., Argaman, M., and Gotschlich, E. C.: Enteric bacteria cross-reactive with Neisseria meningitidis Groups A and $C$ and Diplococcus pneumoniae type 1 and III. Infect. Immunol., 6: 651 (1972).

46. Robbins, J. B., Schneerson, R., Liu, T. Y.. Schiffer, M. S., Schiffman, G. Myerowitz, R. L., McCracken, G. H., Jr., Фrskov, I., and Фrskov, F. Cross-reacting bacterial antigens and immunity to diseases caused by encapsulated bacteria. In: E. Neter and F. Milgrom: Fourth International Convocation on Immunity. University of Buffalo.

47. Sarff, L. D., McCracken, G. H., Jr., Schiffer, M. S., Glode, M. P., Robbins, J. B., Фrskov, I., and Фrskov, K.: Epidemiology of Escherichia coli K I in healthy and diseased newborns. Lancet, $i$ : 7916 (1975).

48. Schiffer, M. S., Oliveira. E., Glode, M. P., McCracken, G. H., Jr., Sarff, L. M. and Robbins, J. B.: Unpublished data.

49. Schnaitman, C. A.: Outer membrane proteins of Escherichia coli. H1. Heterogeneity of major outer membrane polypeptides. Arch. Biochem. Biophys.. 157: 553 (1973). 
50. Schneerson, R., Bradshaw, M. W., Whisnant, J. K., Parke, J. C., Jr., and Robbins, J. B.: An Escherichia coli antigen cross-reactive with the capsular polysaccharide of Haemophilus influenzae type b: Occurrence among known serotypes and immunochemical and biologic properties of $E$. coli antisera towards $H$. influenzae type b. J. Immunol.. I08: 1551 (1972).

51. Smith, R. T., and Eitzman, D. V.: The development of the immune response. Pediatrics, 65: 165 (1964)

52. Smith, T. E., and Bryant, G.: Studies on pathogenic $E$. coli from bovine sources. J. Exp. Med., 46: 155 (1927).

53. Sterzl, J., Mandel, L., Miler, I., and Riha, I.: Development of immune reactivity in the absence of an antigenic stimulus. In: Molecular Basis of Antibody Formation, p. 351 (Czechoslovakia Academy of Sciences, Academic Press, New York, 1965).

54. Stirm, S., rskov, F., rskov, 1., and Mansa, B.: Episome-carried surface antigen K88 of Escherichia coli. II. Isolation and chemical analysis. J. Bacteriol., 93: 731 (1967).

55. Stites, D. P., Wybran, J., Carr, M., and Fudenberg, H. H.: Development of cellular competence in man, In: Ontogeny of Active Immunity, p. 113 (Ciba Foundation Symposium, 1972).

56. Stossel, T. P., Alper, C. A., and Rosen, F. S.: Opsonic activity in the newborn:
Roles of properdin. Pediatrics, 52: 134 (1973).

57. Watson, D. G.: Purulent neonatal meningitis: A study of forty-five cases. J. Pediat., 50: 352 (1957)

58. Wilson, D., Whisnant, J. K., Halterman, H., and Robbins, J. B.: PR P capsular antigen in Haemophilus influenzae type b meningitis: correlation with antibody formation and clinical outcome. (Thirteenth ICAC Proceedings, 1973).

59. Wolberg, G., and deWitt, D.: Mouse virulence of $K(L)$ antigen-containing st rains of Escherichia coli. J. Bacteriol., 100: 730 (1969).

60. Wyle. F. A., Artensetin, M. S., Brandt, B. L., Tramont, E. C., Kasper, D. L. Altieri, P. L., Berman, S. L., and Lowenthal, J. P.: Immunologic response of man to Group B meningococcal polysaccharide vaccines J. Infect. Dis., /26: 514 (1972).

61. Yurchak, A. M., and Austrian, R.: Serologic and genetic relationships between pneumococci and other respiratory streptococci. Trans. Ass. Amer. Phys., 89: $368(1966)$.

62. Requests for reprints should be addressed to: J. B. Robbins, M. D., Division of Bacterial Products, Bureau of Biologics, 8800 Rockville Pike, Bethesda, Md. 20014 (USA).

63. Accepted for publication September 16, 1975.
Cystic fibrosis genetic disease isoelectric focusing $\alpha$-2-macroglobulin protease inhibition

\title{
Studies on Cystic Fibrosis Using Isoelectric Focusing. II. Demonstration of Deficient Proteolytic Cleavage of $\alpha_{2}$-Macroglobulin in Cystic Fibrosis Plasma
}

\author{
GREGORY B. WILSON(61) AND H. HUGH FUDENBERG \\ Section of Immunology, Department of Medicine, University of California, San Francisco, California, and \\ Department of Clinical Immunology and Microbiology, Medical University of South Carolina, Charleston, South
}

Carolina, USA

\section{Extract}

A protein with an isoelectric point (pI) of 5.48 was found to be deficient in plasma from most cystic fibrosis ( $C F$ ) homozygotes and obligate heterozygote carriers for $\mathrm{CF}$ as compared with normal control plasma. Purification of the protein with a pI of 5.48 from normal plasma was performed using ammonium sulfate precipitation, DEAE-cellulose and CM-cellulose chromatography, Sephadex G-200 gel filtration, starch block electrophoresis, and Sepharose 4B gel filtration. The purified protein migrated as a single band on polyacrylamide gel electrophoresis, and displayed a single arc on immunoelectrophoresis against polyvalent antiserum to whole human serum. Results from various techniques used in its characterization indicate that this protein is a fragment of $\alpha_{2}$-macroglobulin $\left(\alpha_{2} \mathbf{M}\right)$ which is derived from $\alpha_{2} \mathbf{M}$ by proteolytic cleavage of intact $\alpha_{2} M$ subunits. Quantitation of $\alpha_{2} M$ levels in plasma indicated no significant differences between levels of $\alpha_{2} \mathrm{M}$ in CF homozygote, obligate heterozygote carrier, or normal control plasma samples. Quantitation of arginine esterase activity in plasma treated with chloroform and ellagic acid indicated that both the total arginine esterase activity and that fraction of arginine esterase activity inhibited by soybean trypsin inhibitor (SBTI) were decreased in most CF homozygote and obligate heterozygote plasma samples relative to normal control values. The results of this study indicate that plasma samples from CF homozygotes and obligate heterozygote carriers for CF show deficient proteolytic cleavage of $\alpha_{2} \mathrm{M}$ as compared with normal control plasma, and suggest that a structural abnormality in $\alpha_{2} \mathbf{M}$ or a deficiency in plasma proteolytic activity may be responsible for this deficiency in proteolysis.

\section{Speculation}

An abnormality in the binding affinity of $\alpha_{2} M$ for plasma proteases may account for the presence of "factors" in CF homozygotes and obligate heterozygote carriers.

Cystic fibrosis is a generalized metabolic disorder. resulting from an unknown genetic defect (33). It is generally thought to be transmitted as a single autosomal recessive trait $(10,33)$, although several authors have found evidence for genetic heterogencity within the clinical entity known as CF $(38,53)$ and have suggested that the disease may actually be a group of closely related genetic abnormalities with similar pathologic consequences (53). Several reports have indicated that sera from patients with CF (CF homozygotes) and from obligate heterozygote carriers contain factors that may be characteristic of the disease and thus possibly related to the primary genetic defect in $\mathrm{CF}(7,11,50,52,53)$. Other factors are found in saliva and sweat from CF homozygotes (31) and have been produced from cultured cells derived from CF homozygotes and heterozygotes (4 6, 13). Partial characterization of the various CF factors suggests that they are closely related 